\title{
A Memorial and Celebration of Life for Kwok Leung
}

A memorial to celebrate the life and legacy of Kwok Leung is planned at the 2015 Academy of Management Meeting in Vancouver. It will be held at the convention center on Sunday 9 August from 4pm-5pm. Kwok's wife, Yumi, is planning to attend. As Kwok's close colleague Ray Friedman has said, 'Having [Yumi] there will help us feel closer to Kwok. And we want [her] to hear firsthand how much he meant to all of us'. To share your memories of Kwok, please also visit the IACMR website message board (www.iacmr.org/2015KwokLeung/ENMessageBoard/).

We truly have lost a wonderful scholar, a humble unassuming individual. To me Kwok has been a friend, a partner, and mentor. We were just starting conversations on major Special Issues for MOR. As many of you may know Kwok built the cross cultural domain of JIBS, he helped me think through a future for MOR that we have been purposely following. He himself has led by example, as a deep thinking scholar always giving of self to build community. I will miss his sunny disposition, easy going manner, and sage advice. Rest in peace.

With best wishes always,

ARIE Y. LEWIN 